\title{
Attitudes towards refugees and Muslim immigrants in Iceland: The perceived link to terrorism
}

\author{
Margrét Valdimarsdóttir, Assistant Professor, Faculty of Social Sciences, \\ Police Science, University of Akureyri
}

Guðbjörg Andrea Jónsdóttir, Director, Social Science Research Institute, University of Iceland

\begin{abstract}
In the past few years, millions have been forced to leave their homes seeking refuge in other countries, most displaced from Muslim majority countries. The inflow of refugees and recent terrorist attacks in Europe may have reinforced prejudice against Muslim immigrants in Europe. Research on these issues is almost non-existent in Iceland. Using a random sample of 3.360 individuals in late 2019 and a survey-based experimental design, we address several questions related to attitudes towards Muslim immigrants and refugees in Iceland. Our results indicate that just over half of the population is willing to accept more refugees than is currently done and does not want to limit the proportion of Muslims among them. Notwithstanding, about $44 \%$ of the public believe that the risk of terrorism will increase if Iceland accepts more immigrants from Muslim majority countries. Political orientation and education are associated with attitudes toward refugees, an association that is partly mediated through stereotypes of Muslims as a security threat. The findings also show that people who are informed that research finds no link between the number of Muslim immigrants and the risk of terrorism are less likely to stereotype Muslim immigrants as a security threat than people who get no such information. This type of information has similar effects on people irrespective of their political orientation. Consequently, the current study does not support the proposition that right-leaning individuals in Iceland are more distrustful of scientific in-
\end{abstract}

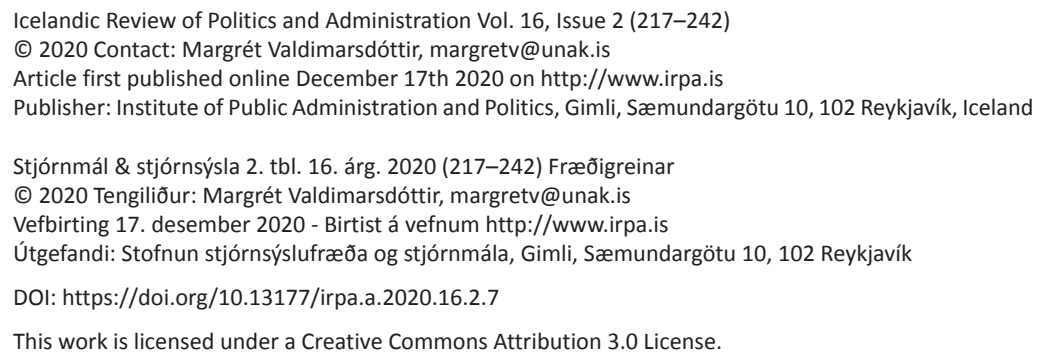


formation than those on the left. The effects are, however, significantly contingent on education.

Keywords: Attitudes towards immigrants; refugees; Muslim immigrants; fear of terrorism; Muslim stereotypes.

\section{Introduction}

The wave of refugees into Europe since 2015 has highlighted anti-immigrant attitudes across the continent and negative attitudes towards Muslims in particular (Wike et al. 2016). The majority of asylum seekers in recent years have been displaced from predominantly Muslim countries, such as Syria, Afghanistan, and Iraq (UNHCR 2019). The surge of refugees, coupled with recent terrorist attacks by Islamist migrants in Europe, has likely reinforced negative Muslim stereotypes (Ferrín, Mancosu, \& Cappiali 2019). Public concerns about the potential security implications of Muslim immigrants and refugees have been exploited by populist political movements, further heightening the threat narrative linking Muslims and refugees with increased risk of terrorism (Dempster \& Hargrave 2017).

While empirical research finds no link between the rate of immigrants from Muslim majority countries and the risk of a terrorist attack (Dragičević 2019; Forrester et al. 2019), results from a survey conducted globally by the Pew Research Center show many people in Europe believe that Muslims and refugees increase the risk of terrorism. This belief is, in turn, associated with negative attitudes towards Muslims and refugees, particularly among those on the right of the political spectrum and individuals with relatively short education (Wike et al. 2016).

In recent years, Iceland has experienced a large growth in its immigrant population. In 2000 , about $5 \%$ of Icelanders were foreign-born but over $18 \%$ in 2020 , which is an increase of more than 240 percent. Likewise, the proportion of non-Icelandic citizens living in Iceland has increased from less than 2\% in 1990 to over 13\% in 2020 (Statistics Iceland 2020a). There has also been an immense growth in applications for asylum in Iceland. The majority of those receiving refugee status in Iceland for the last few years have come from Iran and Syria (Statistics Iceland 2020b).

Iceland has therefore faced similar tasks as many other European countries of receiving and welcoming new residents. Refugee admissions have also been a theme in the political discourse in Iceland as it has in many other western countries. Yet, there is limited research on attitudes towards immigrants in Iceland, particularly towards Muslims and refugees. An analysis of political and media discourse indicates that attitudes towards these groups in Iceland mirror those in other European countries (Tryggvadóttir \& Loftsdóttir 2020). The state police in Iceland has also raised concerns about the potential terrorist threat posed by radicalized young Muslim men among asylum seekers (The National Police Commissioner 2017).

The current research has important theoretical and policy implications. Using survey-based experimental data collected by the Social Science Research Institute, we address several questions related to the public's views of Muslim immigrants and refugees 


\section{STJÓRNMÁL \& \\ STJÓRNSÝSLA}

in Iceland. The current study will also add important new insight into the field by examining if information about facts from scientific research has the potential to reduce prejudice against immigrants. Our three main research questions are:

1. Does the Icelandic public link Muslim immigrants with an increased risk of terrorism (i.e., stereotype Muslim immigrants as a security threat), and what characteristics are associated with the perception of that link?

2. Does fact-based information from scientific research influence people's perception of the link between Muslim immigrants and terrorism, and who is most/ least affected by such information?

3. Is the stereotype of Muslim immigrants as a security threat associated with less support for an increased number of refugees and/or refugees from Muslim majority countries?

During the last ten years, millions have been forced to flee their homes, seeking refuge in other countries. According to the annual Global Trends in Forced Displacement report by UNHCR, the number of asylum seekers will continue to rise (UNHCR 2019). Some people view refugee admissions positively; perhaps as giving a lifeline to a vulnerable population and increasing cultural diversity. Others may be concerned about the fiscal burden of public services, weakened national identity, and increased security threat (Dempster \& Hargrave 2017; Hainmueller \& Hiscox 2007).

The Icelandic government's immigration policy emphasises immigrant integration, equal opportunity, and participation in Icelandic society (The Ministry of Social Affairs 2007). Hostility towards refugees and other immigrants can result in increased challenges and social problems for an already vulnerable group (Strabac et al. 2014). Not addressing some citizens' anxieties, whether they are based on real or perceived threat, may foster anti-immigrant movements that can lead to hate crime and other violence. To be able to address concerns about an increased number of refugees, policymakers and others working on immigration need to understand the source of those concerns.

Our findings indicate that while a large proportion of the Icelandic public favours accepting more refugees than is currently done and does not want to limit the proportion of Muslims among them, negative Muslim stereotypes do exist in Iceland. Further, the stereotype of Muslim immigrants as a security threat is associated with attitudes towards refugees. These stereotypes are more common among people who position themselves on the right of the political spectrum and people with relatively short education.

\section{Previous research on attitudes towards immigrants}

Just as international migration has grown, so has research on attitudes towards immigrants (Hainmueller \& Hopkins 2014). Research conducted in multiple countries shows that immigrants face prejudice and discrimination (Citrin \& Sides 2008; Messina 2007; Zick, Pettigrew, \& Wagner 2008). Unemployment rates are generally higher among firstand second-generation immigrants and refugees than among natives, particularly in 
Western European countries (Adida et al. 2010; Dancygier \& Laitin 2014). In most parts of the world, people have become less accepting of migrants in recent years (Gallup 2020).

Much of early research on attitudes towards immigrants focussed on economic explanations, viewing market competitions and the cost of public services as the main driving force of negative attitudes towards immigrants (see review in Butkus et al. 2018; Mayda 2006). However, more recent studies strongly suggest that concerns about traditional native culture, crime, and security more often motivate hostility towards immigrants (Hainmueller \& Hiscox 2010; Hainmueller \& Hopkins 2014; Hellwig \& Sinno 2017).

One of the strongest predictors of negative attitudes towards immigrants is having relatively short education (Ceobanu \& Escandell 2010; Hainmueller \& Hiscox 2007; Rustenbach 2010). This association has been explained by less-educated natives being fearful of losing their jobs to low-skilled immigrants. Hainmueller and Hiscox (2007, 2010) argued that if job market competition forms attitudes, people should be most opposed to immigrants who have skills similar to their own. Instead, their results, using data from multiple European nations and the US, showed that neither education nor position in the labour market predicts what types of immigrant's people prefer. For example, highly educated people prefer educated and skilled immigrants who, unlike unskilled immigrants, may compete for their jobs. Hainmueller and Hiscox $(2007,401)$ concluded that anti-immigrant attitudes are shaped by a cultural conflict and that educated people have been socialised to place greater value on cultural diversity. Highly educated people are also more likely than others to have lived in a foreign country, which likely diminishes stereotypes of people with different ethnic and cultural backgrounds (Ferrín et al. 2020).

Political orientation is also associated with attitudes towards immigrants. People who position themselves to the left tend to be more positive towards immigrants than right-leaning people (Ceobanu \& Escandell 2010; Ferrín et al. 2020; Pardos-Prado 2011; Rustenbach 2010). Those to the right on the political spectrum may be more concerned about increased tax burden of government spending than individuals who position themselves to the left. There are some indications that right-leaning people have a stronger attachment to national identity than those on the left and emphasise a more exclusionary approach to nationality (Ceobanu \& Escandell 2010). The notion that the western world's culture and security is threatened by increased immigration has also been a part of the political mobilisation of many right-wing parties in Europe in recent years (Rydgren 2005; Wodak et al. 2013). This narrative has likely reinforced negative stereotypes of migrants in right-leaning conservatives more than in people on the left (Arendt et al. 2015; Igartua \& Cheng 2009; Schemer 2012).

\section{Negative stereotypes of refugees and Muslim immigrants}

Native populations in western countries generally favour less culturally distant immigrants. In many European countries, immigrants and refugees from the Middle East are less welcome than other groups (Goodwin et al. 2017; Heath \& Richards 2019; Strabac 


\section{STJÓRNMÁL \& \\ STJÓRNSÝSLA}

\& Listhaug 2008). Individuals from the Middle East have increasingly been portrayed as Muslims (Morey \& Yaqin 2011) who likely face more prejudice than other immigrants. Anti-Muslim sentiments are often a cumulation of a disapproval of the Islamic religion, cultural practices, and of more common prejudice towards an ethnic other (Spruyt \& Elchardus 2012; Strabac \& Listhau 2008). For example, the belief that Muslims identify more strongly with their religion than Christians, are more aggressive and more supportive of terrorism is widespread in Germany (Fischer et al. 2007).

There are, however, also studies that find no difference between attitudes towards Muslim immigrants and other immigrants. For example, Straback and associates (2014) compared attitudes towards Muslim immigrants to attitudes towards immigrants in general (without specifying the background of the immigrant) in four countries. They hypothesised that people are less favourable towards Muslim immigrants than other immigrants in countries that have experienced a large-scale terrorist attack by Islamic extremists (the US and the UK) than in countries that have not (Sweden and Norway). Their results, however, showed that in none of the four countries was there a significant difference between anti-Muslim attitudes and anti-immigrant attitudes (Strabac et al. 2014).

Straback et al. (2014) used two survey questions to measures anti-immigrant attitudes, one stating that immigrants (without specification/with a Muslim background) exploit social security benefits and the other that they should be given the same rights as anyone else. But research has shown that the framing of the questions measuring antiimmigrant attitudes is important as immigrants from different parts of the world are associated with different stereotypes. Hellwig and Sinno's (2017) experimental study in the UK found that while levels of support for increased immigration were similar across different groups of immigrants, people were most likely to agree that immigrants were a security threat when asked specifically about Muslim immigrants. However, people were more likely to associate crime and economic issues with immigrants from Eastern Europe. For example, participants who were asked specifically about immigrants from Eastern Europe were considerably more likely to agree that immigrants abuse the welfare system, take jobs away from other British workers, and commit too much crime, than participants who were asked about immigrants in general or Muslim immigrants.

Since 9/11, people in the western world have become increasingly concerned about terrorism. A recent survey by the Pew Research Center, among almost 42 thousand respondents in 38 countries, showed that over $70 \%$ of Europeans view ISIS as the leading threat to their country, a more serious threat than climate change (Poushter \& Manevich 2017). The political discourse about immigration has centred around security issues, and consequently, fear of terrorism has become inseparable from attitudes towards Muslim immigrants and refugees (Morey \& Yaqin 2011).

A 2016 poll by Brookings showed that $46 \%$ of Americans who opposed accepting refugees were concerned about refugees' links to terrorism (Telhami 2016). Likewise, a survey of ten European countries showed that, in eight of the ten, over half of respondents were worried about the security implications of accepting refugees (Wike et 
al. 2016). Hence, the current study will test if the stereotype of Muslims as a security threat, linking them with increased risk of terrorism in Iceland, is associated with attitudes towards refugees and attitudes towards the proportion of Muslims among refugees.

\section{Attitudes towards immigrants and refugees in Iceland}

Compared with attitudes in other countries, the Icelandic public tends to have a favourable disposition towards immigrants (Gallup 2020; Önnudóttir 2009; Karlsson 2017). Although research is limited, studies indicate that people in Iceland are also positive towards refugees. In a survey conducted in 2015, a random sample of just over 1,000 Icelandic citizens were asked "how many refugees from Syria do you think that Iceland should accept in the next 12 months?". In that year, 106 individuals did receive refugee status in Iceland (Statistic Iceland 2020c) but participants in the study were not given information about that number. The majority of those asked, supported accepting over 150 refugees from Syria in that year. In a similar survey conducted a year later, just under $73 \%$ of participants agreed that the Icelandic government should do more to help those who were fleeing war or persecution, but a somewhat smaller proportion of the public (around 65\%) was willing to accept refugees to their own neighbourhood. According to Amnesty International in Iceland, a somewhat higher proportion of the public in Iceland is positive towards refugees than in many other countries (Amnesty 2016).

It is still unclear if the growth of the immigrant population in Iceland has resulted in a more favourable or a more negative attitude towards immigrants. Research by Önnudóttir (2009) found that Icelanders were less positive towards immigrants in 2008 than they were in 2005. A more recent study found that people were less accepting of immigrants in 2019 than in 2017 (Social Science Research Institute 2019).

Eva Heiða Önnudóttir (2009) suggested that the Icelandic public may be hospitable towards immigrants when they believe that immigrants increase the country's economic prosperity but become more negative in times of recession and increased unemployment. This finding is in line with research conducted in other European countries (Dancygier \& Laitin 2014). The same study also found that people in Iceland tend to be less accepting of immigrants with different racial or cultural background from themselves, and less accepting of immigrants from "poorer countries outside Europe than from poorer countries within Europe" (Önnudóttir 2009, 76).

For a few decades, Iceland has participated in the European Values Study (EVS) where members of the public have been asked to identify a group that they would not like as a neighbour. Figure 1 shows the results for the proportion of the public who selected immigrant/foreign workers and Muslims at four different time points. At each time, a considerably higher proportion of Icelanders selected Muslims than immigrants or foreign workers. The figure also indicates that fewer Icelanders were negative towards Muslims in 2008 than in 1990 and 1999, but that the proportion who were negative towards Muslims rose again in 2017. 


\section{STJÓRNSÝSLA}

To put the data in Figure 1 in cross-national context, the figure also shows the proportion of the public who was negative towards immigrants and Muslims in the other Nordic countries as well as an average for other European countries (28 countries) in 2017 (the most recent year available). Figure 1 supports findings from previous studies cited above, namely that in comparison to people in other countries the Icelandic public tends to be positive towards immigrants. Although in 2017, the proportion of the Icelandic public who did not want Muslims as neighbours was still larger than the proportion in both Norway and Sweden.

Figure 2 shows data from the Icelandic Election Study in 2017. Although over 70\% of the Icelandic public believed that immigrants are good for the Icelandic economy, and few believed that immigrants harm Icelandic culture, almost a third thought that immigrants increase crime rates in Iceland.

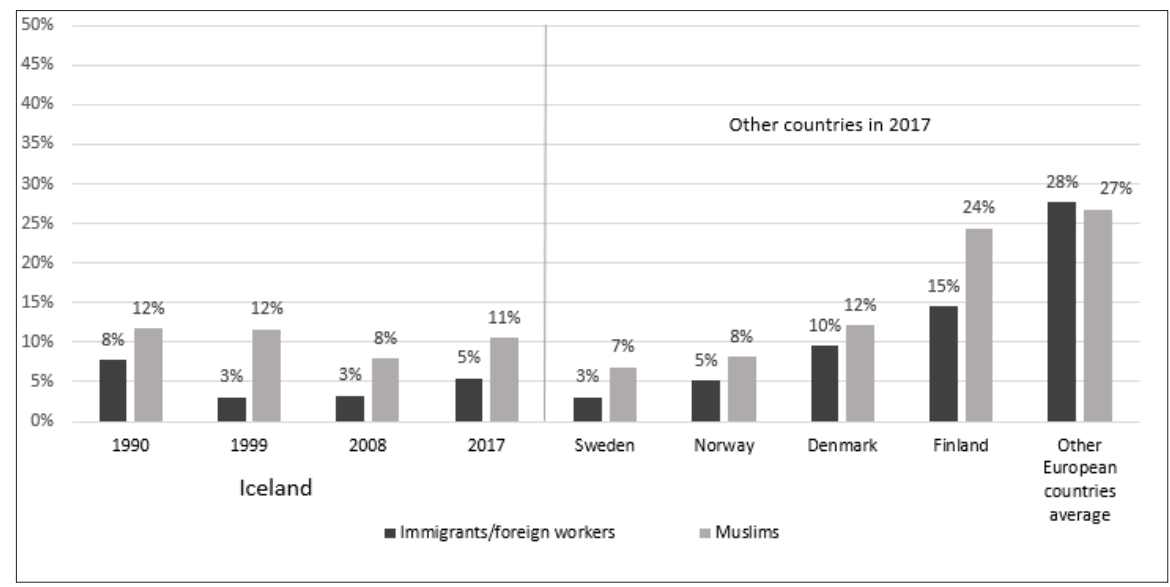

Figure 1. Percentage of the public who would not like to have ... as neighbours ${ }^{1}$

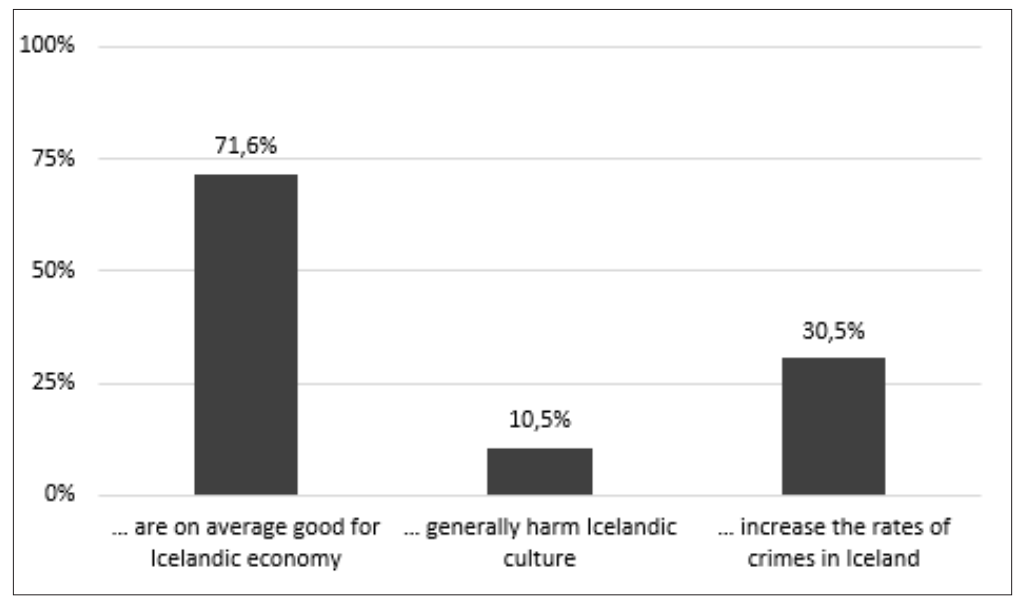

Figure 2. Percentage of the Icelandic public in 2017 who agrees that immigrants ... 2 
In sum, the results from various surveys conducted in Iceland strongly indicate that attitudes towards immigrants are not one dimensional. While most people are positive when asked about immigrants in general, natives in Iceland tend to be discriminatory towards culturally distant groups (such as Muslims). There is also some indication that Icelanders have stereotypical ideas about immigrants linking them with crimes, but we do not know if these stereotypes influence people's attitudes towards immigrants in general.

\section{The current research}

Previous research points to two main characteristics as predictors of stereotypes of immigrants and perceived risk of terrorism; political orientation and education (Anderson \& Ferguson 2018; Ferrín et al. 2020; Wike et al. 2016). While immigration has not been politicalized to the same extent in Iceland as in many other countries, results from surveys conducted in Iceland do indicate that party affiliation is associated with attitudes towards immigrants (Social Science Research Institute 2019).

The three research questions are disaggregated into several sets of hypotheses depicted in the analytical model in Figure 3. Our first hypothesis (H1a) is that individuals who position themselves to the right on the left-right political scale and (H1b) those without a university degree are more likely than others to hold negative Muslim stereotypes. While negative stereotypes of Muslims include a wide range of beliefs about religious and cultural practices in Muslim majority countries (Fischer et al. 2007), we specifically focus on the stereotype of Muslims as a security threat, linking Muslim immigrants to increased risk of terrorism in Iceland. We also expect political orientation and education to predict negative attitudes towards refugees (H2). To be able to answer if attitudes towards refugees in Iceland are rooted in attitudes towards Muslims, we will also test attitudes towards Muslim refugees specifically.

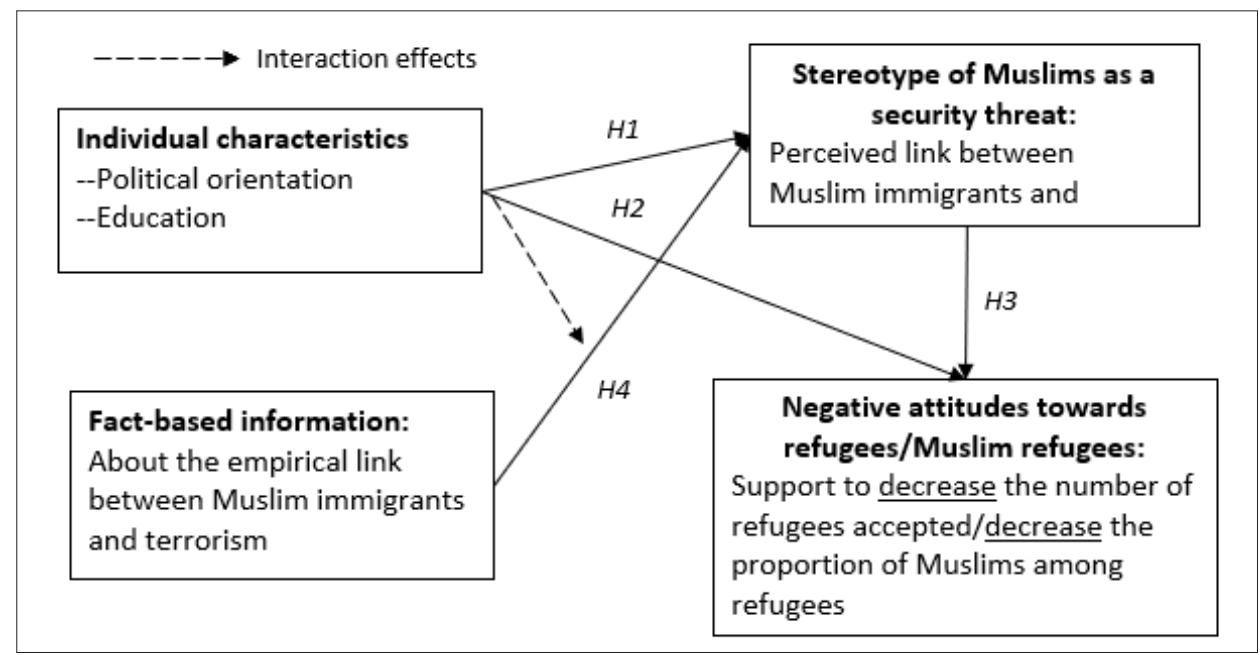

Figure 3. Analytical model being tested 


\section{STJÓRNMÁL \& \\ STJÓRNSÝSLA}

H1: Individuals on the political right and those without a university education are more likely than others to stereotype Muslims as a security threat.

$\mathrm{H} 2$ : Individuals on the political right and those without a university education are more likely than others to support a decreased number of refugees in Iceland and a decreased proportion of Muslims among refugees.

The current study will also test if attitudes towards refugees (and the proportion of Muslims among refugees) can be explained by the perceived link between Muslim immigrants and terrorism. In other words, do people who oppose accepting refugees to Iceland do so because they believe that an increased number of Muslim immigrants will lead to an increased risk of terrorism? Attitudes towards refugees can, alternatively, be rooted in values and believes which are not related to threats to security. Thus, we test if the relationship between individual characteristics and attitudes towards refugees is mediated through stereotypes of Muslims as a security threat (H3).

H3: The relationship between individual characteristics and negative attitudes towards refugees is mediated by stereotypes of Muslims as a security threat.

If one ignores the complexity of definitions of terrorism, then the deadliest terrorist groups worldwide are self-proclaimed Islamists (the Taliban, ISIL, the Khorasan Chapter of the Islamic State, and Boko Haram). Over $90 \%$ of the victims of these groups are people in Muslim majority countries in the Middle East, South-Asia, and North-Africa (Institute for Economics and Peace 2019). Yet, there have been several deadly attacks in recent years in major European cities. These attacks against civilians that have been committed by individuals or groups with migrant background claiming a connection to ISIS have received immense media attention (attacks such as in Paris and Brussels in 2015, Nice and Berlin in 2016, and Manchester and London in 2017). Therefore, linking terrorism with Islamic extremism is not irrational.

However, the number of people killed by terrorism in Europe for the last two decades is still far smaller than have been killed by other types of violence (Ritchie et al. 2019). There is also no empirical association between the proportion of Muslim immigrants and terrorist attacks in the host country (Dragičević 2019; Forrester et al. 2019). If negative stereotypes of Muslims as terrorists are due to a misperception, heightened by the media, receiving fact-based information should diminish these stereotypes. If the belief that Muslim immigrants increase the risk of terrorism is more emotive and valuedriven or rooted in prejudice against culturally distant groups, such information is not likely to impact people's attitudes.

The current study uses experimental design assigning a large sample randomly into 
two groups, one getting information stating that scientific research finds no correlation between number of immigrants from Muslim majority countries and the risk of terrorism in the host country, and the other group receiving no such information. Both groups were asked to evaluate the consequences of an increased number of Muslim immigrants in Iceland on the risk of terrorism. Hypotheses 4 states that individuals who receive fact-based information will be less likely to state that an increased number of Muslim immigrants will increase terrorism in Iceland.

H4: Fact-based information reduce stereotypes of Muslims as a security threat.

Research suggests that scientific evidence impacts different groups differently (Dempster \& Hargrave 2017). Some studies indicate that distrust in science is on the rise and that it may be more common among people on the political right and those with a relatively short education (Gauchat 2012; Nichols 2017). In line with previous research, the current study will also test if fact-based information about scientific research findings impact different groups differently (i.e., an interaction shown with the dotted lines in Figure 3).

\section{Method}

\subsection{Data and sample}

The analyses are based on data from the Social Science Research Institute (SSRI) at the University of Iceland. A random sample of 5.981 individuals from the SSRI internetpanel received an e-mail invitation to participate in an anonymous online survey on topics related to security and other social issues. The SSRI internet-panel is based on a random sample from the Icelandic population. The sample is invited to be a part of the panel which involves participating in various anonymous social surveys 2-4 times a year. The data was collected from September 27th through November 5th, 2019. The final sample included 3.360 respondents (56\% completion rate). The sample was weighted by education, age, location (urban/rural) and gender to represent the Icelandic population more accurately ${ }^{3}$.

\subsection{Experimental design}

We use experimental design to test hypothesis 4 . In other words, to discover if people who receive fact-based information about empirical research on Muslim immigrants and terrorism are less likely to view Muslim immigrants as a security threat than those who receive no such information. All participants were asked: Over the next ten years, do you think that the risk of terrorism in Iceland will increase if we choose to accept more immigrants from Muslim majority countries in Africa, Asia, and the Middle East? Participants were randomly divided into two groups. One group (i.e., the treatment group) received the following prolog to the question: For your information, researchers who have analysed the link between an increased number of immigrants from Muslim majority countries and terrorist attacks in the host countries have found no link. 


\section{STJÓRNMÁL \& \\ STJÓRNSÝSLA}

\subsection{Measures}

A description of the three dependent variables and their response categories is shown in Figures 4, 5, and 6. Political orientation is measured with an 11-point left-right selfplacement scale. The respondents were asked: "The discussion about "left" and "right" is common in politics. Where would you position yourself on the following scale where 0 stands for furthest to the left and 10 stands for furthest to the right?". In the analyses below, we use two dummy variables for education. The original question "what is your highest level of education?" had 8 response categories from: 1) finished compulsory education only to 8) a doctoral degree. We combined categories resulting in three groups:

1. Individuals with compulsory education only are used as a reference category in the regression analyses (Icelandic law states that education is mandatory for children and adolescents between the ages of 6 and 16).

2. Those who have finished upper secondary education such as comprehensive school, industrial-vocational school, or special vocational school were combined into a group.

3. Individuals who have finished a degree from a university were combined into the category university education.

Proportions of participants in each category are shown in Table 1. We use a dummy variable for gender using females as the reference category $(0)$ and coded males with 1. The weighted sample includes an approximately equal number of males and females. Age is measured in number of years. While the capital area is about 1.03 percent $(1,062$ $\mathrm{km}^{2}$ ) of the size of Iceland, it is home to about $64 \%$ of the population. Consequently, we use the capital area as a proxy for urban area and people who live in the larger capital area were coded 1 on the variable urban, and individuals who live in other parts of the country represent the reference category, which is coded 0 .

To isolate the hypothesised relationships, we also include models that control for some covariates of attitudes towards immigrants; general trust of other people (i.e., interpersonal trust), institutional trust, and fear of crime (Andersen \& Mayerl 2018; Rustenbach 2010). General trust was measured with the following three survey items: 1) "Generally speaking, would you say that most people can be trusted or that you can never be too careful in dealing with people?", 2) "Would you say that most people would take advantage of you if they got the chance or that most people try to be fair?", and 3) "Would you say that most of the time, people try to be helpful or that people mostly look out for themselves?". Participants were asked to answer using a number from 0 to 10 , where 0 referred to lack of trust and 10 to high trust in other people. The items were combined into an index using the mean score of the 3 items $(\alpha=0.81)$.

Institutional trust was measured with 10 survey items: "How much or little do you trust the following institutions: 1) the parliament, 2) the justice system, 3) the police, 4) politicians, 5) political parties, 6) the European Union, 7) the United Nations, 8) the 
University of Iceland, 9) the banking system, and 10) the national church. The response category ranged from one (do not trust at all) to seven (trust completely). The items were combined into an index using the mean score of the 10 items $(\alpha=0.87)$.

Participants were asked "how secure or insecure they felt when they were walking alone in 1) their own neighbourhood/area, and 2) downtown Reykjavík after dark". Response categories ranged from 1) very secure to 4) very insecure. The mean score of the two items was used to measure fear of crime. Descriptive statistics of all measures used in the study are shown in Table 1.

\section{Results}

\subsection{Descriptive results}

Table 1 presents descriptive statistics of all measures used in the analyses below. The mean of the variable measuring the perception of a link between Muslim immigrants and terrorism is 4.67 (s.d. = 1.10), which indicates that people are somewhat likely to believe that there is a link (see also Figure 4). The mean for the dichotomous (dummy) variables is the proportion in each group. For example, about $30 \%$ of the weighted sample have compulsory education only, about 35\% upper secondary education and $36 \%$ a university degree.

Table 1. Descriptive statistics (weighted sample)

\begin{tabular}{lrrrr}
\hline & Mean & St. Dev. & Min & Max \\
\hline The perceived link between Muslim immigrants and terrorism & 4.67 & 1.10 & 1 & 7 \\
Support to decrease the number of accepted refugees & 3.60 & 1.79 & 1 & 7 \\
Support to decrease the proportion of Muslims among refugees accepted & 3.62 & 1.93 & 1 & 7 \\
Political ideology (left-right scale) & & & 10 \\
Compulsory education & 4.80 & 2.20 & 1 & 1 \\
Upper secondary education & 0.30 & 0.46 & 0 & 1 \\
University education & 0.35 & 0.48 & 0 & 1 \\
Male & 0.36 & 0.48 & 0 & 1 \\
Age & & & 0 \\
Urban & 0.50 & 0.50 & 18 & 93 \\
General trust & 46.02 & 17.69 & 18 \\
Institutional trust & 0.64 & 0.48 & 0 \\
Fear of crime & & 6.12 & 2.06 & 0 \\
\hline
\end{tabular}

In Figure 4, the perception of a link between Muslim immigrants and terrorism is compared between individuals who received fact-based information (stating that research has found no such link) with those who did not receive information. The figure shows that most people, in both groups, believe that over the next ten years, the risk of ter- 


\section{STJÓRNSÝSLA}

rorism in Iceland will neither increase nor decrease if we accept more immigrants from Muslim majority countries. As expected, a lower percentage of those receiving the information (the prolog) believe that the risk of terrorism will increase with increased number of Muslim immigrants. Among individuals who did not receive information, $43.5 \%$ believe that the risk of terrorism in Iceland will increase with increased number of Muslim immigrants but only about $35 \%$ of those receiving fact-based information. The results in Figure 4 indicate that stereotypes of Muslims as a security threat do exist among the Icelandic public.

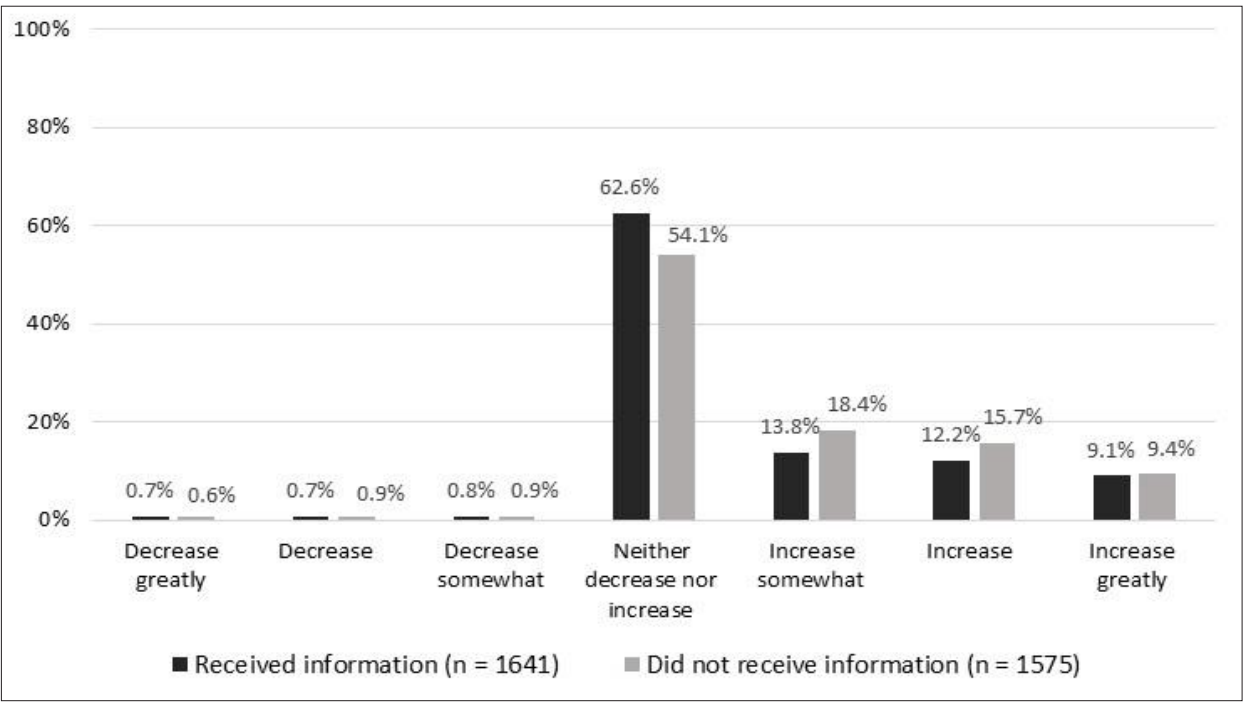

Figure 4. Stereotypes of Muslims as a security threat: The Perceived link between Muslim immigrants and terrorism

Note: Q. Over the next ten years, do you think the risk of terrorism in Iceland will increase if we choose to accept more immigrants from Muslim countries in Africa, Asia, and the Middle East? The risk of terrorism will...

Attitudes towards refugees and refugees with a Muslim background are overall rather favourable. In other words, almost half of participants think that Iceland should receive more refugees than is now done (see Figure 5). About forth of participants think that Iceland should neither accept more nor less refugees than it does today. Likewise, about $44 \%$ of all participants disagree with the statement that Iceland should reduce the proportion of refugees with a Muslim background (see Figure 6), but just under third of participants neither agree nor disagree with the statement. 


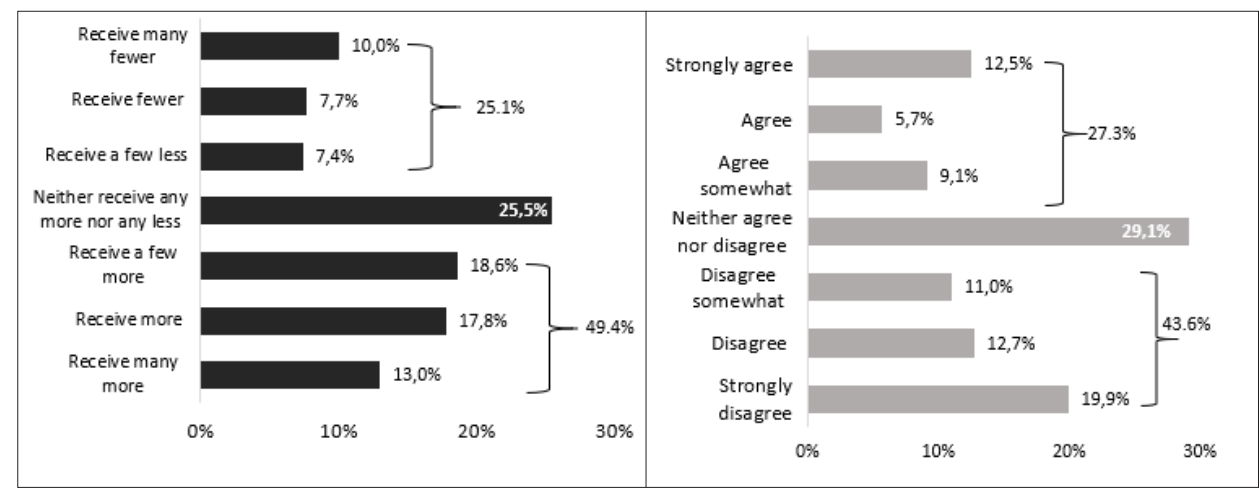

Figure 5. Attitudes towards refugees

Note: Q. There is an ongoing debate in Iceland about how many refugees we should receive. Do you think that Iceland should receive more or fewer refugees than it does today?
Figure 6. Attitudes towards Muslim refugees

Note: Q. To what extent do you agree or disagree that Iceland should reduce the proportion of refugees with a Muslim background?

\subsection{Analytical results}

In Table 2 we turn to the regression analyses predicting stereotypes of Muslims as a security threat (testing $\mathrm{H} 1$ and H4). Model 1 shows that individuals who received fact-based information score significantly lower on the measure of these stereotypes, although the difference is small (0.089 on a scale from 1 to 7$)$. Political orientation is a much better predictor of stereotypes of Muslims as a security threat than whether one received the information. All else being equal (i.e., when other variables in the model are controlled for), a one-point increase to the right on the political scale is associated with an average of 0.145 increase in the measure of a perceived link between Muslim immigrants and terrorism.

Education is strongly associated with stereotypes of Muslims as a security threat. The results in Model 1 (in Table 2) show that those with a university degree are significantly less likely to report Muslims as a security threat than those with compulsory education only $\left(\mathrm{b}=-0.428^{* * *}\right)$. People with upper secondary education are also less likely than those with compulsory education, to view Muslims as a security threat, although the difference is small. The model also shows that these types of ideas about Muslims significantly increase with increased age $\left(b=0.008^{* * *}\right)$, but that gender and residence (urban/rural) have no impact.

In model 2, we have added an interaction term for political orientation by factbased information. The coefficient for the interaction term enables us to examine if the impact of information on viewing Muslims as a security threat is contingent on political orientation. The coefficient for the interaction effect is not significant, indicating that the information has similar impact on people on the left and right of the political spectrum. However, the results in model 3 show that there is a significant interaction between education and fact-based information. 


\section{STJÓRNSÝSLA}

Thus, the perception of a link between Muslim immigrants and terrorism is similar among individuals with compulsory education who received information (treatment group) and those who did not (control group). The treatment (getting fact-based information) does however significantly impact individuals with a university degree $(\mathrm{b}=$ $\left.-0.203^{*}\right)$. Making participants with a university degree who received fact-based information less likely to perceive Muslims as a security threat than any other group. This interaction is visually presented in Figure 7.

Finally, in model 4 we have added three additional variables that may correlate with both the independent and dependent variable. After controlling for general trust, institutional trust, and fear of crime, all of the effects observed in Model 1 still hold. Hence, after controlling for any distrust that individuals may have towards other people and institutions in society and for fear of crime, political orientation and education are still associated with a perceived link between Muslim immigrants and the risk of terrorism. Importantly, the coefficient for the treatment is essentially the same as in model 1, giving us further confidence that getting fact-based information about the empirical link between Muslim immigrants and the risk of terrorism reduces the stereotype of Muslims as a security threat, instead of it being an artifact of general distrust in institutions, distrust in other people, or fear of crime.

Table 2. OLS regression predicting stereotypes of Muslims as a security threat: Perceived link between Muslim immigrants and terrorism in Iceland

\begin{tabular}{|c|c|c|c|c|}
\hline N 2998-3012 & Model 1 & Model 2 & Model 3 & Model 4 \\
\hline & $B(\beta)$ & $B(\beta)$ & $B(\beta)$ & $B(\beta)$ \\
\hline Fact-based information (treatment) & $-0.089(-0.041)^{*}$ & $-0.039(-0.018)$ & $0.044(0.020)$ & $-0.084(-0.038)^{*}$ \\
\hline Political orientation (right) & $0.145(0.293)^{* * *}$ & $0.151(0.304)^{* * *}$ & $0.145(0.294)^{* * *}$ & $0.158(0.319)^{* * *}$ \\
\hline Upper secondary education & $-0.088(-0.038)+$ & $-0.088(-0.038)+$ & $-0.002(-0.001)$ & $-0.010(-0.005)$ \\
\hline University education & $-0.428(-0.188)^{* * *}$ & $-0.428(-0.188)^{* * *}$ & $-0.326(-0.143)^{* * *}$ & $-0.222(-0.098)^{* *}$ \\
\hline Male & $-0.020(-0.009)$ & $-0.020(-0.009)$ & $-0.020(-0.009)$ & $0.026(0.012)$ \\
\hline Age & $0.008(0.132)^{* * *}$ & $0.008(0.133)^{* * *}$ & $0.008(0.130)^{* * *}$ & $0.010(0.156)^{* * *}$ \\
\hline Urban & $-0.024(-0.011)$ & $-0.025(-0.011)$ & $-0.021(-0.009)$ & $-0.036(-0.016)$ \\
\hline General trust & --- & --- & --- & $-0.075(-0.140)^{* * *}$ \\
\hline Institutional trust & --- & --- & --- & $-0.113(-0.108)^{* * *}$ \\
\hline Fear of crime & --- & --- & --- & $0.166(0.111)^{* * *}$ \\
\hline \multicolumn{5}{|l|}{ Interactions } \\
\hline Political orientation* information & & $-0.010(-0.027)$ & & \\
\hline College educ. ${ }^{*}$ information & & & $-0.172(-0.060)+$ & \\
\hline University educ*information & & & $-0.203(-0.072)^{*}$ & \\
\hline Constant & $3.85 * * *$ & $3.82 * * *$ & $3.78 * * *$ & $4.12^{* * *}$ \\
\hline Adj. $R^{2}$ & 0.15 & 0.15 & 0.15 & 0.20 \\
\hline F-value & $74.55^{* * *}$ & $65.27 * * *$ & $58.66 * * *$ & $77.07 * * *$ \\
\hline
\end{tabular}

$\mathrm{B}=$ unstandardized coefficient $(\beta)=$ standardized coefficient

$* \mathrm{p}<.05 \quad * * \mathrm{p}<.01 \quad * * * \mathrm{p}<.001$ 


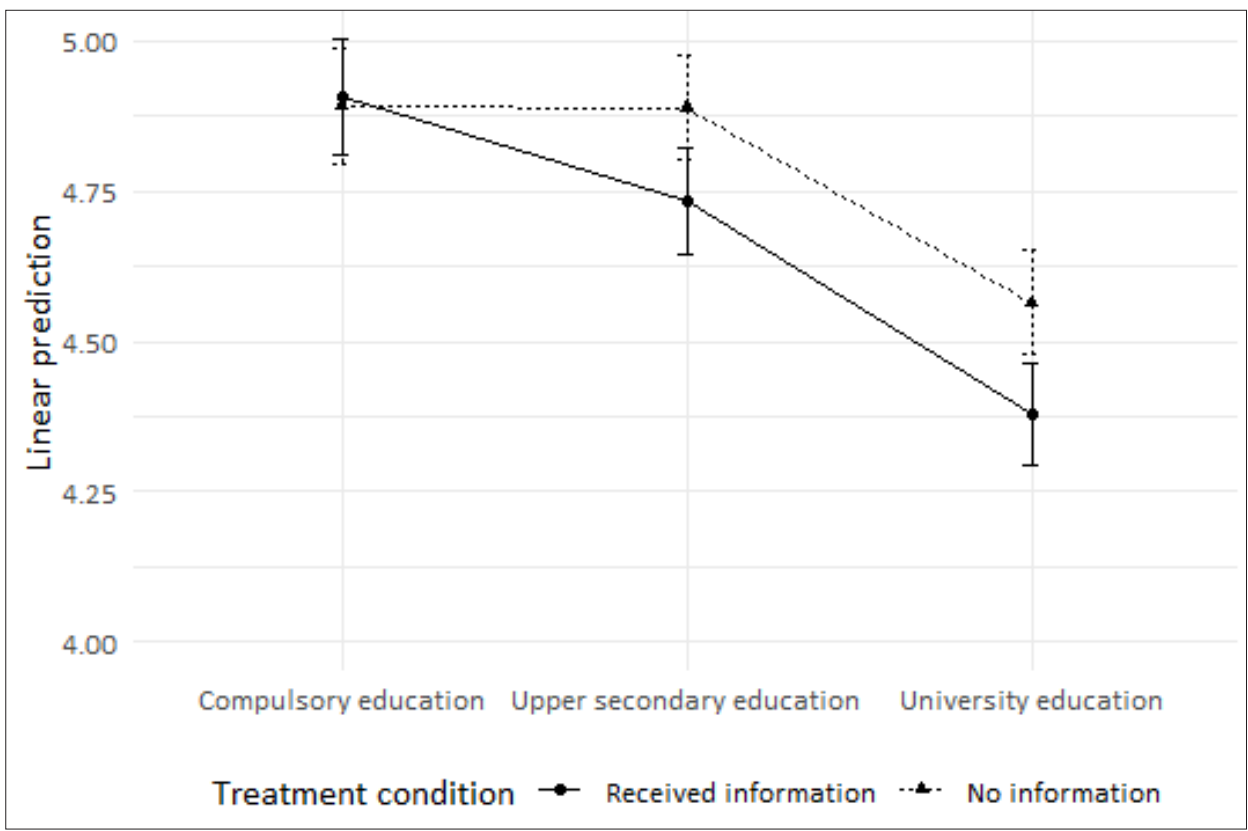

Figure 7. Interaction effects between receiving text with information from scientific research and education on perceived link between Muslim immigrants and terrorism

In Table 3, we examine attitudes towards refugees, i.e., the support to decrease the number of refugees in Iceland. As was hypothesised (H2), both political orientation and education are associated with attitudes towards refugees. Individuals who position themselves on the left have a significantly more positive attitude towards accepting refugees than those on the right of the political scale $\left(\mathrm{b}=0.269^{* * *}\right)$. Likewise, people with an upper secondary education and those with a university degree are significantly more likely to support accepting more refugees than those with shorter education. The average difference between people with compulsory education only and a university degree is substantial $\left(\mathrm{b}=-1.022^{* * *}\right)$. The results in Table 3 also show that age is significantly and negatively associated with attitudes towards refugees. Individuals who live in urban areas are also more positive towards refugees. The difference in the attitudes towards refugees between women and men is not significant.

In model 2 (Table 3), the variable measuring the stereotype of Muslims as a security threat has been added to the equation. The model lends considerable support for hypothesis 4 , namely that these stereotypes are associated with negative attitudes towards refugees in general (instead of just Muslim refugees). After adding the stereotype of Muslims as a security threat to the model, the coefficients for political orientation and education remain statistically significant but become smaller. The impact that political orientation and education has on attitudes towards refugees is thus only partly mediated through the perceived security threat posed by Muslim immigrants. 
Table 3. OLS regression predicting attitudes toward refugees (support to decrease the number of refugees in Iceland)

\begin{tabular}{lccc}
\hline $\mathrm{N}=2990-3004$ & Model 1 & Model 2 & Model 3 \\
\hline Stereotypes of Muslims as a security threat & $\mathrm{B}(\beta)$ & $\mathrm{B}(\beta)$ & $\mathrm{B}(\beta)$ \\
Political orientation(right) & --- & $0.813(0.499)^{* * *}$ & $0.766(0.471)^{* * *}$ \\
Upper secondary education & $0.269(0.334)^{* * *}$ & $0.150(0.186)^{* * *}$ & $0.163(0.203)^{* * *}$ \\
University education & $-0.318(-0.085)^{* * *}$ & $-0.248(-0.066)^{* * *}$ & $-0.194(-0.052)^{* *}$ \\
Male & $-1.022(-0.276)^{* * *}$ & $-0.676(-0.182)^{* * *}$ & $-0.538(-0.145)^{* * *}$ \\
Age & $0.075(0.021)$ & $0.083(0.023)$ & $0.051(0.014)$ \\
Urban & $0.014(0.14)^{* * *}$ & $0.008(0.079)^{* * *}$ & $0.011(0.107)^{* * *}$ \\
General trust & $-0.179(-0.048)^{* *}$ & $-0.162(-0.044)^{* *}$ & $-0.174(-0.047)^{* *}$ \\
Institutional trust & --- & --- & $-0.100(-0.115)^{* * *}$ \\
Fear of crime & --- & --- & $-0.058(-0.034)^{*}$ \\
\hline Constant & --- & -- & $0.001(0.001)$ \\
\hline Adj. $\mathrm{R}^{2}$ & $2.18^{* * *}$ & $-0.92^{* * *}$ & $-0.11^{* * *}$ \\
\hline F-value & 0.22 & 0.34 & 0.45 \\
\hline
\end{tabular}

$\mathrm{B}=$ unstandardized coefficient $(\beta)=$ standardized coefficient

$* \mathrm{p}<.05 \quad * * \mathrm{p}<.01 \quad * * * \mathrm{p}<.001$

The results in Model 3, show that general trust towards other people in society is negatively associated with attitudes towards refugees $\left(b=-0.100^{* * *}\right)$. Thus, people who tend to mistrust other people are less accepting of refugees. Institutional trust is also significantly associated with attitudes towards refugees, in the same direction, although the correlation is weaker $\left(\mathrm{b}=-0.058^{*}\right)$ than between general trust and attitudes towards refugees. Fear of crime is, however, not associated with attitudes towards refugees. Controlling for these three variables has little impact on previously observed relationships.

In table 4, we examine attitudes towards Muslim refugees specifically. Overall, the relationships observed when focusing on refugees in general (in Table 3) are almost identical to the results shown in Table 4. Notwithstanding, the stereotype of Muslims as a security threat does have a stronger impact on attitudes towards Muslim refugees than on refugees in general. The differences in attitudes towards Muslim refugees between those with university education and those with a compulsory education only is also not as large in Table 4 as in Table 3. 
Table 4. OLS regression predicting support to decrease the proportion of Muslims among the refugees accepted to Iceland

\begin{tabular}{lccc}
\hline $\mathrm{N}=$ 2994-3008 & Model 1 & \multicolumn{1}{c}{ Model 2 } & \multicolumn{1}{c}{ Model 3} \\
\hline Stereotypes of Muslims as a security threat & $\mathrm{B}(\beta)$ & $\mathrm{B}(\beta)$ & $\mathrm{B}(\beta)$ \\
Political orientation(right) & -- & $0.912(0.516)^{* * *}$ & $0.876(0.495)^{* * *}$ \\
Upper secondary education & $0.287(0.328)^{* * *}$ & $0.153(0.175)^{* * *}$ & $0.162(0.185)^{* * *}$ \\
University education & $-0.181(-0.045)^{*}$ & $-0.094(-0.023)$ & $-0.062(-0.015)$ \\
Male & $-0.773(-0.192)^{* * *}$ & $-0.380(-0.095)^{* * *}$ & $-0.288(-0.072)^{* * *}$ \\
Age & $0.042(0.011)$ & $0.058(0.015)$ & $0.039(0.010)$ \\
Urban & $0.031(0.286)^{* * *}$ & $0.024(0.218)^{* * *}$ & $0.026(0.237)^{* * *}$ \\
General trust & $-0.152(-0.038)^{*}$ & $-0.125(-0.031)^{*}$ & $-0.131(-0.033)^{* *}$ \\
Institutional trust & --- & --- & $-0.079(-0.083)^{* * *}$ \\
Fear of crime & --- & --- & $-0.023(-0.012)$ \\
\hline Constant & -- & --- & $0.014(0.005)$ \\
\hline Adj. $\mathrm{R}^{2}$ & $6.79^{* * *}$ & $-2.26^{* * *}$ & $-1.73^{* * *}$ \\
\hline F-value & 0.25 & 0.47 & 0.48 \\
\hline
\end{tabular}

$\mathrm{B}=$ unstandardized coefficient $(\beta)=$ standardized coefficient

* $\mathrm{p}<.05 \quad * * \mathrm{p}<.01 \quad{ }^{* * *} \mathrm{p}<.001$

\section{Discussion}

Because of a significant increase in migration and asylum seekers, understanding public attitudes towards immigrants has become a vital task for those working on issues related to immigration. While migration frequently benefits migrants and their families, it can also contribute to the host country's economic growth and development (Feridun 2005; UN Popul. Div. 2019). Prejudice and negative public attitudes towards these oftensensitive groups can, however, hinder successful integration and the well-being of the migrant (Wike et al. 2016; for a review, see Butkus et al. 2018).

Recent research indicates that the public in many European countries has become more hostile towards external migrants (Gallup 2020), particularly towards Muslim refugees (Wike et al. 2016). These changes in public sentiment may be due to media attention around the so-called wave of asylum seekers from predominantly Muslim countries, but it may also be because of several deadly terrorist attacks committed by self-proclaimed Islamists in recent years (Ogan et al. 2013). Muslims have increasingly been portrayed as the "threatening other" in the public discourse, and it is unclear whether people in western countries make a distinction between radical Muslims and Muslims in general.

Research reviewed in this paper indicates that, when compared to the public in other countries, Icelanders are generally positive towards immigrants. There are, however, some signs that the acceptance of immigrants is decreasing in Iceland (SSRI 2019; Önnudóttir 2009). There is also some indication that the Icelandic public is less positive 
towards culturally distant groups (e.g. Muslims) than immigrants in general. But research on public attitudes towards refugees has been limited in Iceland. This is unfortunate as public attitudes potentially impact the well-being of new arrivals (Wike et al. 2016; Butkus et al., 2018).

The current study adds valuable new knowledge to the research field by focussing on attitudes towards refugees. We also examined if Icelanders view Muslim immigrants as a potential security threat; increasing the risk of terrorism in Iceland. Our results show that about a quarter of the adult population believes that Iceland should decrease the number of refugees accepted, and almost 30\% of the public agree that Iceland should limit the proportion of Muslims among refugees accepted to Iceland. About the same proportion of the population wants to keep the current state of things. Hence, the group who wants to accept more refugees, and does not want to limit the proportion of Muslims among them, is larger than the one that feels the opposite. Considering that Iceland has accepted fewer refugees per capita than many similar nations (OECD 2019), it is unclear if the findings presented here should be interpreted as Icelanders being positive or negative towards refugees. This question calls for a normative rather than an empirical answer.

The results in this study indicate that the stereotype of Muslims as a security threat exists in Iceland. A considerable proportion of the public (about 44\%) believes that the terrorist risk will increase if we accept more immigrants from Muslim majority countries. Muslim immigrants in Iceland may, therefore, face similar prejudice as have been reported in other countries (Fischer et al. 2007; Strabac \& Listhaug 2008).

Building on previous literature, we hypothesised that people who position themselves to the left on the political spectrum and university educated individuals would be less likely to stereotype Muslim immigrants as a security threat and to have more positive attitudes towards refugees (of Muslim origin as well as refugees in general). We also hypothesised that a part of the impact of political orientation and education on attitudes towards refugees would be mediated through the perceived link between Muslim immigrants and terrorism. In other words, we suggested that the opposition towards accepting refugees can, at least partly, be explained by stereotypes of Muslims as a security threat. All three hypotheses were supported in the study. Stereotypes of Muslims as a security threat are associated with not only attitudes towards Muslim refugees, but also with refugees in general. Our results therefore support the proposition that prejudice against Muslims in Western countries (i.e., the stereotype of the Muslim terrorist) is related to the opposition that some people have against refugee admissions.

Notwithstanding, after controlling for the perceived link between Muslim immigrants and terrorism, political orientation and education are still significantly associated with attitudes towards refugees. Thus, concerns about increased risk of terrorism is not the only explanation of why people who position themselves on the right of the political spectrum and people with a relatively short education are less likely than other groups to favour accepting more refugees in Iceland. These groups may, for example, be concerned about the fiscal burden of public services or potential changes in national identity (Dempster \& Hargrave 2017; Hainmueller \& Hiscox 2007). 
Finally, we used a survey-based experiment to test if fact-based information, about research showing no link between the rate of immigrants from predominantly Muslim countries and terrorist attacks, has the potential to decrease the fear that Muslim immigrants pose a security threat to Iceland. Our findings show that people who receive such information are significantly less likely to stereotype Muslims as a security threat than those in the control group (who received no information). This type of information has similar impact on groups independent of their political orientation. Consequently, the current study does not support the proposition that right-leaning individuals in Iceland are more distrustful of scientific information than those on the left. The effects are, however, significantly contingent on education. These results indicate that fact-based information can influence attitudes of university educated individuals but have limited to no effects on those with less education.

This study has limitation that should be noted. First, survey questions about attitudes towards immigrants may be subject to social desirability bias, i.e. respondents may be hesitant to admit to having negative attitudes that are not in accordance with social norms (Krumpal 2014). This might suggest that the results presented here underestimate real prejudice and negative attitudes towards Muslim immigrants. However, comparisons between countries show that the Icelandic public tends to be positive towards immigrants in an international context. In addition, studies have shown that social desirability bias is contingent on the mode of data collection with the smallest bias in self-administered modes such as web surveys (cf. Kreuter, Presser, \& Tourangeau 2008), as is used in the current study. This is furthermore supported by experimental data from the European Values Study in 2017 (Luijkx et al. 2020; EVS 2020) were respondents in Iceland were twice as likely to admit that they did not like to have Muslims as their neighbours in an online web survey as they were in a face to face interview.

The second potential limitation concerns our experimental design, in particular the finding that getting fact-based information seems to impact university educated people more than those with less education. Various artifacts may be present in experimental conditions, effects caused by subjects' awareness of being the object of observation (Orne 1962, 1969; Rosenthal 1966). Respondents in a survey are cognisant of their role as the object of study and are likely to respond to cues in the questionnaire, demand characteristics, that may enable them to behave in ways that are likely to support the researcher's hypotheses. Context effects on attitudinal questions (e.g., a prolog with factbased information as in our study) have sometimes been treated as 'measurement artifacts' (Schuman 1982). This implies that attitudes are stable. In her study, Jónsdóttir (2004) argues that in most cases measures of attitudes are susceptible to context. In their ground-breaking book on response effects in surveys, 'Questions and Answers in Attitude Surveys', Schuman and Presser (1981) suggested that educated respondents might more easily grasp the general meaning of the question and be less likely to be influenced by emotionally coloured words. However, they suspected that these respondents might at the same time be more sensitive to precise wording of questions. Hence, they thought it conceivable that education might not always moderate the magnitude of response ef- 


\section{STJÓRNMÁL \& \\ STJÓRNSÝSLA}

fects, but that better educated respondents might even under some circumstances show a stronger effect as we see in our study. This, we believe is not an artifact of design, but rather a natural phenomenon due to the training that more educated respondents have had and making them more receptive to fact-based information about scientific research.

Finally, we measure attitudes towards refugees by asking people if they think that Iceland should accept more or fewer refugees than it currently does. However, we do not assume that people know the number of refugees accepted each year. Neither do we assume that people know exactly if Iceland accepts many or few refugees per capita compared to other countries. This type of information is seldomly mentioned in the media when immigration or matters related to asylums seekers are discussed. Rather, our measure captures general dispositions towards refugee admissions among the Icelandic public.

An important contribution of our study has been to use a survey-based experiment to examine attitudes towards refugees in a large random sample of the Icelandic public. By focussing on a potential intervening mechanism between personal characteristics and attitudes towards refugees we have also added a new insight to further the understanding of people's views on immigration. While our results indicate that a large proportion of the Icelandic public is positive towards accepting refugees, the results also indicate that some people may fear increased security threat posed by refugees who have been displaced from predominantly Muslim countries. It has been reasoned that security concerns about refugees gain traction in people's minds because they feed into a worldview where cultural outsiders are seen as a threat (Dempster \& Hargrave 2017), which may explain why information alone does not have a strong impact on previously held believes. Attitudes towards refugees and immigrants are most likely driven by a complex spectrum of emotions. Understanding these emotions is essential as attempts to reduce prejudice are unlikely to succeed without that understanding

\section{Acknowledgement}

This work was supported by Nordforsk (Grant No. 88043).

\section{Notes}

1 Icelandic participants in EVS who selected immigrants/foreign workers or Muslims when asked "On this list are various groups of people. Could you identify any that you would not like to have as neighbours?". Participants could select one or more of the following groups: People of a different race, heavy drinkers, immigrants/foreign workers, drug addicts, homosexuals, Christians, Muslims, Jews, Gypsies, or No. I wouldn't mind having any of these as neighbours.

2 Data available here: https://fel.hi.is/is/islenska-kosningarannsoknin-2017, https://doi. org/10.34881/1.00011

3 Females, university educated, older age groups and those living in rural areas are usually more likely than other groups to participate in surveys, and thus non-response is not random. Weighting the responses of underrepresented groups is a common practice to correct for this type of non-response bias (Groves et al. 2011). For example, individuals with compulsory education are about $11 \%$ of the unweighted data but almost $30 \%$ of the weighted data. Other variables were less affected by the weight. 


\section{References}

Adida, C.L., Laitin, D.D., and Valfort, M.A. (2010). "Identifying Barriers to Muslim Integration in France", Proceedings of the National Academy of Sciences 107(52), 22384-22390. https://doi. org/10.1073/pnas.1015550107

Anderson, J., and Ferguson, R. (2018). "Demographic and Ideological Correlates of Negative Attitudes towards Asylum Seekers: A Meta-Analytic Review", Australian Journal of Psychology 70, 18-29.

Amnesty (2016). “Tæplega 74\% landsmanna telja að íslensk stjórnvöld ættu að gera meira til að hjálpa flóttafólki". Viewed on 19 September at https://amnesty.is/frettir/taeplega-74-landsmanna-teljaad-islensk-stjornvold-aettu-ad-gera-meira-til-ad-hjalpa-flottafolki

Arendt, F., Marquart, F., and Matthes, J. (2015). "Effects of Right-Wing Populist Political Advertising on Implicit and Explicit Stereotypes", Journal of Media Psychology 27(4), 178-189. https://doi. org/10.1027/1864-1105/a000139

Butkus, M., Maciulyte-Sniukiene, A., Matuzeviciute, K., and Davidaviciene, V. (2018). "Society's Attitudes towards Impact of Immigration: Case of EU Countries", Marketing and Management of Innovations 1, 338-351. http://doi.org/10.21272/mmi.2018.1-26

Ceobanu, A.M., and Escandell, X. (2010). "Comparative Analyses of Public Attitudes Toward Immigrants and Immigration Using Multinational Survey Data: A Review of Theories and Research", Annual Review of Sociology 36(1), 309-328. https://doi.org/10.1146/annurev.soc.012809.102651

Citrin, J., and Sides, J. (2008). "Immigration and the Imagined Community in Europe and the United States", Political Studies 56(1), 33-56. https://doi.org/10.1111/j.1467-9248.2007.00716.x

Dancygier, R.M., and Laitin, D.D. (2014). "Immigration into Europe: Economic discrimination, violence, and public policy", Annual Review of Political Science 17, 43-64.

Dempster, H., and Hargrave, K. (2017). Understanding Public Attitudes towards Refugees and Migrants (Working paper 512). Chatham House. The Royal Institute of International Affairs. https://www.odi.org/ sites/odi.org.uk/files/resource-documents/11600.pdf

Dragičević, D. (2019). "Is there any Correlation between Terrorism and Immigration? Evidence from EU Countries", Journal of Business Paradigms 4(2), 4-21.

EVS (2020). European Values Study 2017: Integrated Dataset (EVS 2017) - Matrix Design Data. GESIS Data Archive, Cologne. ZA7502 Data file Version 2.0.0. https://doi.org/10.4232/1.13561

Ferrín, M., Mancosu, M., and Cappiali, T.M. (2020). “Terrorist Attacks and Europeans' Attitudes towards Immigrants: An Experimental Approach”, European Journal of Political Research 59(3), 491-516. https://doi.org/10.1111/1475-6765.12362

Fischer, P., Greitemeyer, T., and Kastenmüller, A. (2007). "What Do We Think about Muslims? The Validity of Westerners' Implicit Theories about the Associations between Muslims' Religiosity, Religious Identity, Aggression Potential, and Attitudes toward Terrorism", Group Processes \& Intergroup Relations 10(3), 373-382. https://doi.org/10.1177/1368430207078697

Forrester, A.C., Powell, B., Nowrasteh, A., and Landgrave, M. (2019). "Do Immigrants Import Terrorism?", Journal of Economic Behavior \& Organization 166, 529-543. https://doi.org/10.1016/j. jebo.2019.07.019

Gallup (2020). World Grows Less Accepting of Migrants. Gallup. Viewed on 5 October at https://news.gallup.com/poll/320678/world-grows-less-accepting-migrants.aspx

Gauchat, G. (2012). "Politicization of Science in the Public Sphere: A Study of Public Trust in the United States, 1974 to 2010", American Sociological Review 77(2), 167-187.

Goodwin, M., Raines, T., and Cutts, D. (2017). "What Do Europeans Think About Muslim Immigration?", Chatham House, 7. February. Viewed on 5 October at https://www.chathamhouse. $\operatorname{org} / 2017 / 02 /$ what-do-europeans-think-about-muslim-immigration

Groves, R.M., Fowler Jr., F.J., Couper, M.P., Lepkowski, J.M., Singer, E., and Tourangeau, R. (2011). Survey methodology (2 $2^{\text {nd }}$ ed.). New York: Wiley.

Hainmueller, J., and Hiscox, M. J. (2007). "Educated Preferences: Explaining Attitudes Toward Im- 
migration in Europe", International Organization 61(2), 399-442. https://doi.org/10.1017/ S0020818307070142

Hainmueller, J., and Hiscox, M.J. (2010). "Attitudes toward Highly Skilled and Low-skilled Immigration: Evidence from a Survey Experiment”, American Political Science Review 104(1), 61-84. https://doi. org/10.1017/S0003055409990372

Hainmueller, J., and Hopkins, D. J. (2014). "Public Attitudes Toward Immigration", Annual Review of Political Science 17(1), 225-249. https://doi.org/10.1146/annurev-polisci-102512-194818

Heath, A., and Richards, L. (2019). "How Do Europeans Differ in Their Attitudes to Immigration: Findings from the European Social Survey 2002/03 - 2016/17”, OECD Social, Employment and Migration Working Papers 222. https://doi.org/10.1787/0adf9e55-en

Hellwig, T., and Sinno, A. (2017). "Different Groups, Different Threats: Public Attitudes towards Immigrants", Journal of Ethnic and Migration Studies 43(3), 339-358. https://doi.org/10.1080/136918 3X.2016.1202749

Igartua, J.J., and Cheng, L. (2009). "Moderating Effect of Group Cue While Processing News on Immigration: Is the Framing Effect a Heuristic Process?", Journal of Communication 59(4), 726-749. https://doi.org/10.1111/j.1460-2466.2009.01454.x

Institute for Economics and Peace (2019). Global Terrorism Index 2019: Measuring the Impact. Institute for Economics and Peace. http://visionofhumanity.org/reports

Jonsdottir, G.A (2004) Context Effects in Social Surveys: A Study of Question Order Effects (PhD thesis). London School of Economics and Political Science, UK.

Karlsson, E. (2017). Nýbúinn. Viðhorf til innflytjenda á Íslandi (BA dissertation in Sociology). Viewed 19 September at https://skemman.is/bitstream/1946/27388/1/N\%C3\%BDb\%C3\%BAinnFinal.pdf

Kreuter, F., Presser, S., and Tourangeau, R. (2008). "Social Desirability Bias in CATI, IVR and Web Surveys: The Effects of Mode and Question Sensitivity", Public Opinion Quarterly 72(5), 847-865. doi:10.1093/poq/nfn063

Krumpal, I. (2014). "Social Desirability Bias and Context in Sensitive Surveys", in A.C. Michalos (ed.), Encyclopaedia of Quality of Life and Well-Being Research. Springer, Dordrecht. https://doi. org/10.1007/978-94-007-0753-5_4086

Luijkx, R., Jónsdóttir, G.A., Gummer, T., Ernst Stähli, M., Frederiksen, M., Ketola, K., Reeskens, T., Brislinger, E., Christmann, P., Gunnarsson, S.P., Hjaltason, Á.B., Joye, D., Lomazzi, V., Maineri, A.M., Milbert, P., Ochsner, M., Pollien, A., Sapin, M., Solanes, I., Verhoeven, S., and Wolf, C. (2020). "The European Values Study 2017: On the Way to the Future Using Mixed-Modes", European Sociological Review jcaa049. https://doi.org/10.1093/esr/jcaa049

Mayda, A.M. (2006). "Who Is Against Immigration? A Cross-Country Investigation of Individual Attitudes toward Immigrants", Review of Economics and Statistics 88(3), 510-530. https://doi. org/10.1162/rest.88.3.510

Messina, A. (2007). The Logics and politics of Post-WWII Migration to Western Europe. UK: Cambridge University Press.

MMR (2015). Tap 90\% vilja taka á móti flóttamönnun frá Sýrlandi. https://mmr.is/frettir/birtarnieurstoeeur/492-taep-90-vilja-taka-a-moti-flottamoennun-fra-syrlandi

Morey, P., and Yaqin, A. (2011). Framing Muslims: Stereotyping and Representation after 9/11. US: Harvard University Press.

Nichols, T. (2017). The Death of Expertise: The Campaign Against Established Knowledge and Why it Matters. UK: Oxford University Press.

OECD (2019). The Road to Integration: Education, Migration and Social Cohesion. OECD. https://doi. org $/ 10.1787 / \mathrm{d} 8$ ceec $5 \mathrm{~d}$-en

Ogan, C., Willnat, L., Pennington, R., and Bashir, M. (2013). "The rise of anti-Muslim prejudice: Media and Islamophobia in Europe and the United States", International Communication Gazette 76(1), 27-46. https://doi.org/10.1177/1748048513504048 
Orne, M.T. (1962). "On the Social Psychology of the Psychological Experiment: With Particular Reference to Demand Characteristics and Their Implications", American Psychologist 17, 776-783.

Orne, M.T. (1969). „Demand Characteristics and the Concept of Quasi-Controls”, in R. Rosenthal and R.L. Rosnow (eds.), Artifact in Behavioral Research (pp. 143-179). New York: Academic Press.

Pardos-Prado, S. (2011). "Framing Attitudes Towards Immigrants in Europe: When Competition Does Not Matter", Journal of Ethnic and Migration Studies 37(7), 999-1015. https://doi.org/10.1080/1369 183X.2011.572421

Poushter, J., and Manevich, D. (2017). Globally, People Point to ISIS and Climate Change as Leading Security Threats Concern about cyberattacks, world economy also widespread. Pew Research Center. https://www. pewresearch.org/global/2017/08/01/globally-people-point-to-isis-and-climate-change-as-leadingsecurity-threats/\#in-europe-and-u-s-isis-is-seen-as-a-major-threat

Ritchie, H., Hasell, J., Appel, C., and Roser, M. (2019). Terrorism. Our World in Data. https://ourworldindata.org/terrorism

Rosenthal, R. (1966). Experimenter Effects in Behavioral Research. New York: Appleton-Century-Crofts.

Rustenbach, E. (2010). "Sources of Negative Attitudes toward Immigrants in Europe: A MultiLevel Analysis", International Migration Review 44(1), 53-77. https://doi.org/10.1111/j.17477379.2009.00798.x

Rydgren, J. (2005). "Is extreme right-wing populism contagious? Explaining the emergence of a new party family", European Journal of Political Research 44(3), 413-437.

Schemer, C. (2012). "The Influence of News Media on Stereotypic Attitudes Toward Immigrants in a Political Campaign", Journal of Communication 62(5), 739-757. https://doi.org/10.1111/j.14602466.2012.01672.x

Schuman, H. (1982). "Artifacts Are in the Mind of the Beholder", The American Sociologist 17, 21-28.

Schuman, H., and Presser, S. (1981). Questions and answers in attitude surveys: Experiments on question form, wording and context. New York: Academic Press.

Social Science Research Institute (2019). Könnun á viðhorfum almennings til innflytjenda og fjölmenningarsamfélagsins. Social Science Research Institute. https://www.stjornarradid.is/library/04-Raduneytin/ Felagsmalaraduneytid/Vi\%c3\%b0horf_\%20til_innflytjenda_september_2019.pdf

Spruyt, B., and Elchardus, M. (2012). "Are Anti-Muslim Feelings More Widespread than Anti-Foreigner Feelings? Evidence from Two Split-Sample Experiments", Ethnicities 12(6), 800-820. https://doi. org/10.1177/1468796812449707

Statistics Iceland (2020a). "Mannfjöldi, bakgrunnur". Viewed on 11 November at http://px.hagstofa. is/pxis/pxweb/is/Ibuar/Ibuar_mannfjoldi_3_bakgrunnur/?rxid=321352a1-ff8c-4192-8774c3507dad7395

Statistics Iceland (2020b). "Mannfjöldi, bakgrunnur, Alpjóðleg vernd og dvalarleyfi". Viewed on 11 November at https://px.hagstofa.is/pxis/pxweb/is/Ibuar/Ibuar_mannfjoldi_3_bakgrunnur_ Vernd_dvalarleyfi/MAN45002.px

Strabac, Z., Aalberg, T., and Valenta, M. (2014). "Attitudes towards Muslim Immigrants: Evidence from Survey Experiments across Four Countries”, Journal of Ethnic and Migration Studies 40(1), 100-118. https://doi.org/10.1080/1369183X.2013.831542

Strabac, Z., and Listhaug, O. (2008)." Anti-Muslim Prejudice in Europe: A Multilevel analysis of Survey Data from 30 Countries", Social Science Research 37(1), 268-286. https://doi.org/10.1016/j.ssresearch.2007.02.004

Telhami, S. (2016). "American Attitudes Toward Muslims and Islam”. Brookings, 27. July. https://www. brookings.edu/blog/markaz/2016/07/27/poll-shows-american-views-on-muslims-and-the-middle-east-are-deeply-polarized/

The Ministry of Social Affairs (2007). Stefna ríkisstjórnarinnar um adlögun innflytjenda. The Ministry of Social Affairs. https://www.stjornarradid.is/media/velferdarraduneyti-media/media/acrobat-skjol/ Stefna_um_adlogun_innflytjenda.pdf 
The National Police Commissioner (2017). Skipulög glapastarfsemi 2017: Mat greiningardeildar ríkislögreglustjóra á skipulagdri glapastarfsemi. The National Police Commissioner. https://www.logreglan.is/wp-content/uploads/2017/10/Skipul\%C3\%B6g\%C3\%B0-brotastarfsemi-2017_23_ okt $\%$ C3 $\%$ B3ber_loka $\%$ C3\%BAtg $\%$ C3\%A1fa.pdf

Tryggvadóttir, H., and Loftsdóttir, K. (2020). "The Word I Hate: Racism, Refugees and Asylum Seekers in Iceland”, Icelandic Review of Politics \& Administration 16(1), 23-42. https://doi.org/10.13177/ irpa.a.2020.16.1.2

Wike, R., Stokes, B., and Stewart, R. (2016). Europeans Fear Wave of Refugees Will Mean More Terrorism, Fewer Jobs. Pew Research Center. https://www.pewresearch.org/global/2016/07/11/europeansfear-wave-of-refugees-will-mean-more-terrorism-fewer-jobs/

Wodak, R., KhosraviNik, M., and Mral, B. (2013). Right-Wing Populism in Europe: Politics and Discourse. A\&C Black.

Zick, A., Pettigrew, T.F., and Wagner, U. (2008). "Ethnic Prejudice and Discrimination in Europe”, Journal of Social Issues 64(2), 233-251. https://doi.org/10.1111/j.1540-4560.2008.00559.x

Önnudóttir, E.H. (2009). „Viðhorf Íslendinga til innflytjenda á Íslandi“" Bifröst Journal of Social Science 3, 67-95. 
